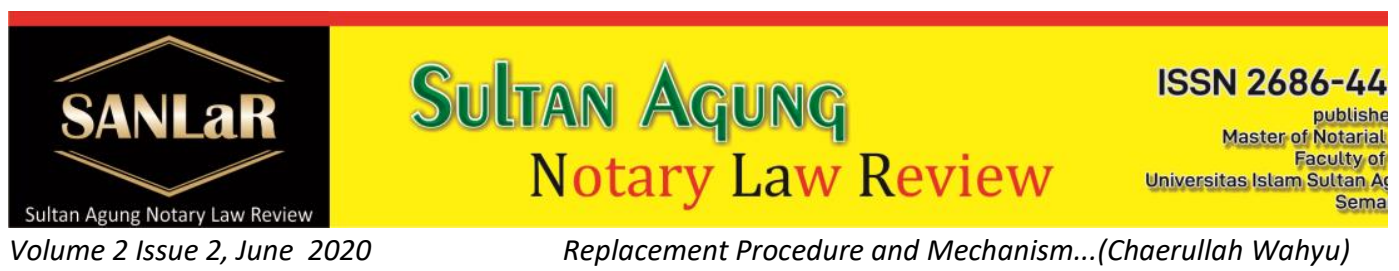

\title{
Replacement Procedure and Mechanism Lost Minuta Deed Due Natural Disaster
}

\author{
Chaerullah Wahyu*) and Amin Purnawan ${ }^{* *}$ \\ *) Students of Master of Notary Law, Universitas Islam Sultan Agung (UNISSULA) \\ Semarang, E-Mail: chaerul.wahyu44@gmail.com \\ ${ }^{* *}$ Lecturer of Master of Notary Law, Universitas Islam Sultan Agung (UNISSULA) \\ Semarang
}

\begin{abstract}
The purpose of this study as follows: 1) to identify and explain the procedures and mechanisms replacement of Lost Minuta Due due to natural disasters that occurred in Palu, Central Celebes. 2) to identify and explain the barriers and solution procedures and mechanisms replacement of Lost Minuta Due due to natural disasters that occurred in Palu, Central Celebes. The method used in this research is descriptive using normative juridical approach. Sources of data obtained by collecting primary data and secondary data. Primary data were collected by interview and secondary data obtained through primary legal materials, secondary law and tertiary legal materials. Based on the results of this research to know that the procedures and mechanisms Replacement of Lost Minuta Due Natural Disaster is Making a report that the notary with Lost Minuta Deed to the police, but if the minutes of the deed is lost due to force majeure or break up the core of the minutes of the deed can not be read again the notary shall make an official report which will then be submitted to the news event MPW or MPD. 1) make a report to the police to report content that the notary concerned has lost all documents and other important files. 2) send the report to the Minister of Justice and Human Rights of the Republic of Indonesia concerning the condition of the notary's office damaged by natural disasters. 3) send a letter containing a report to the Director of the Department of Civil Law and Human Rights of the Republic of Indonesia, Directorate General of Legal Administration, Solution: 1) heirs to apply for approval of the minutes of the notary deed or protocol to the notary who willing to accept the minutes of a notary deed or protocol of the notary who had died or disappeared because of natural disasters. 2) notary willing to accept the minutes of a notary deed or protocol to apply to the Minister of Justice and Human Rights of the Supervisory Council cq region of Central Celebes province of Indonesia concerning the appointment of the protocol. 3) after a petition submitted and accepted by the Supervisory Council of the Territory, then the Regional Supervisory Council issued a decree on appointment of notaries container protocol of notary who died or disappeared because of natural disasters.
\end{abstract}

Keywords: Replacement; Mechanism; Lost Minuta Deed; Natural Disaster. 


\section{Introduction}

From birth until death in the world, people are always hanging out with other human beings in a container called society. ${ }^{1} \mathrm{~A}$ fact of life that human beings can not live alone. This is in line with the opinion of an expert thought the Greeks, Aristotle stated "it is Zoon Politicon man, it means that human beings are basically always wanted to hang out and get together with other human beings, so the creature of society. And because it is like to hang out with each other, then the man is called a social being." ${ }^{2}$ Him self living side by side even in groups and frequently entered into a relationship with one another.

Relationships that occur in connection with the need for life may not always be fulfilled itself. Needs of human life is diverse and for the fulfillment depends on the results obtained in the efforts undertaken. Every time people want to meet their needs well. If in the same time two people want to meet a need that is also equal to the object needs only one and both will not budge, there will be a clash. A clash would occur even when the relationship between man and another man there who do not meet their obligations.

According E.Utrecht states that the law is a set of life instructions, commands and prohibitions, which set the order in a society, and should be adhered to by members of the public concerned, therefore breach the life instructions can lead to action by the government or the public authorities. ${ }^{3}$

So are the provisions of law arising out of and in the association of human life. The emergence of a sense of human consciousness by itself, as a social phenomena that are the result of the measurement of human behavior in social life. ${ }^{4}$

Article 1 of Notary law is known, that the principal task of the notary is to make the deeds authentic. ${ }^{5}$ The authentic act is one of the documents referred to minutes of the deed, so the Minuta deed created and prepared by notary Minuta deed who later became the document/records state that must be maintained and stored properly in order not to be lost or damaged. ${ }^{6}$

\footnotetext{
${ }^{1}$ Tosa, A. Halim. (1996). Pengantar IImu Hukum Indonesia. Banda Aceh: Faculty of Syariah IAIN ArRaniry. p. 25

${ }^{2}$ C.S.T.Kansil. (1989). Pengantar Ilmu Hukum Dan Tata Hukum Indonesia. Jakarta: Balai Pustaka. p. 29

${ }^{3}$ Ali, Achmad. (2009). Menguak Teori Hukum (Legal Theory) dan Teori Peradilan (Judical prudence) termasuk Interpretasi Undang-Undang (Legisprudence). Jakarta: Kencana. p. 432

${ }^{4}$ Djamali, R. Abdoel. (1993). Pengantar Hukum Indonesia. Jakarta: Raja Grafindo Persada. p. 2

${ }^{5}$ Notodisoerjo, R. Soegondo. (1993). Hukum Notaris Indonesia Suatu Penjelasan. Jakarta: Rajawali Pers. p. 8

${ }^{6}$ Herlina, Lely. (2016). Jurnal: "Analisis Yuridis Terhadap Kelalaian Notaris Dalam Penyimpanan Minuta Akta". Malang: Universitas Brawijaya. p. 4
} 
A very real example during a natural disaster of the earthquake in the city of Palu in 2018. The offices of notary there devastated even destroyed resulting in Minuta deed stored and maintained for this to be damaged even some missing Minuta deed tsunami brought water. So basically, keep minutes of deed it is incumbent notary, so that should save his own notary protocols (which contains the minutes of the deed), or by an employee who has been entrusted to carry out the Minuta deed storage and do not let the notary protocols held by others. This is because the notary protocol is a collection of documents that are the state archives to be stored and maintained by a notary.

This is what can cause the Minuta deed lost without the knowledge of the notary. If the Minuta deed is lost, it can be said not to perform its obligations store notary Minuta deed properly. In this case, under Article 16, point 11 of Act No. 12 of 2014 concerning Notary, if in violation of the rules that have been determined, it can be subject to sanctions in the form of:

a. Written Warning;

b. While dismissal;

c. Dismissal With Regards; or

d. Dismissal With Not Yours.

\section{Research Methods}

This study uses normative method ${ }^{7}$ which discusses the normative doctrines or principles in jurisprudence. ${ }^{8}$ The research material was obtained through a normative juridical approach that is supported by empirical juridical approach. The nature of this research is descriptive analytical research that describes all the symptoms and deed that occur in the field as well as linking and analyzing all the symptoms and the fact that the existing problems in the research and then adapted to the circumstances that occurred in the field. ${ }^{9}$

\section{Result and Discussion}

\subsection{Replacement Procedures and Mechanisms of Lost Minuta Deed Due Natural Disaster In Kota Palu, Central Celebes}

UUJN is unification in the areas Notary, meaning that only the rule of law in the form of laws governing notary positions in Indonesia, so that all matters relating

\footnotetext{
7 Soemitro, Roni Hanitijo. (1988). Metode Penelitian Hukum dan Jurimetri. Jakarta: Ghalia Indonesia. p. 11

${ }^{8}$ Ali, Zainuddin. (2009). Metode Penelitian Hukum. Jakarta: Sinar Grafika. p. 24

${ }^{9}$ Surakhmad, Winarno. (1978). Dasar dan Teknik Research. Bandung: Tarsito. p. 132
} 
to the Indonesian notary must refer to UUJN. ${ }^{10}$ Article 1 Reglement of Het Notary ambt in Indonesie Staatsblad 1860 No. 3 states: ${ }^{11}$

De Notarissen zijn openbare ambtenaren, uitsluitend bevoegd om authentieke akten op te maken wegens alle handelingen, overeenkomsten en beschikkingen, waarvan eene the General Verordening gebiedt of de belanghebbenden verlangen, dat bij authentiek geschrift blijken zal, daarvan de dagtekening te verzekeren, de akten in Bewaring te houden en daarvan grossen, afshriften en uittreksels uit te geven; alles voorzover opmaken dier akten door het ene Algemene Verordening ook niet aan andere ambtenaren of personen opgedragen of voorbehouden is.

Minuta is the original deed notarial deed. Understanding Minuta in this case meant the original certificates that are stored in the notary protocol. In this minuta also contained original signatures, initials Client or thumbprint of the left and right hands, the witnesses and the notary, Renvoi ${ }^{12}$ and other evidence supporting the deed attached to the Minuta deed. Deed in the form minuta shall be kept by the notary ${ }^{13}$. Given the number of monthly and entered into the register of the notarial deed (Repertorium) and given a number Repertorium.

Notarial deed was generated in the form of minutes of copies can be made the same sound or the contents in accordance with the request of the Client, people who are entitled or heirs, unless otherwise specified by legislation ${ }^{14}$ by a notary in question or the holder of the protocol. ${ }^{15}$

Notary protocol is a collection of documents, either a certificate or other important papers were in the possession and maintenance of a notary. This set of documents is the state archives. Notary protocol settings can be seen in Article 1 point to 13 from UUJN, as a document which is the state archives to be stored and maintained by a notary.

\footnotetext{
10 Adjie, Habib. (2005). Undang-Undang Jabatan Notaris (UUJN) Sebagai Unifikasi Hukum Pengaturan Notaris, Renvoi, Nomor 28 of III, 3 September 2005. p. 38

${ }^{11}$ This means that the notary is a public official only authorized to make authentic act on all deeds, agreements and determination required by a general rule or by the interested to be stated in an authentic deed, ensure certainty the date, save the deed and give grosse, copy and excerpts.

12 Renvoi means appointment to record in the deed of additional, and replacement legalized graffiti, R. Soegondo Notodisoerjo, Op. Cit., p. 175

${ }^{13}$ Article 16 paragraph (1) letter b and paragraph (2) UUJN

${ }^{14}$ Article 54 UUJN confirms Notaries can only give, show, or notify the contents of the deed, Grosse certificate, copy of the deed or the excerpt deed, to the person directly concerned in the deed, heirs, or persons who are entitled, unless otherwise specified by legislation,

${ }^{15}$ The issue or give, show, or memberithaukan contents of the deed, Grosse Deeds, Copy of Deed or Deed citation, the person of interest directly on the deed, heirs, or persons who are entitled, unless otherwise stipulated by legislation.
} 
Especially for Minuta and copy or excerpt Notary shall make it in on paper, as has been done so far $^{16}$ can not be made in electronic media (as the Electronic Document), it is associated with the provisions of Article 5 (1) and (4) of the Law on Information and Electronic Transaction, that: ${ }^{17}$

a. Electronic Information and/or Electronic Document and/or prints a legitimate legal proof.

b. Provisions concerning Electronic Information and/or Electronic Documents as referred to in paragraph (1) shall not apply to:

1) note that under the Act must be made in written form.

2) letter along with the documents that under the Act must be made in the form of Minuta deed made by deed officials.

The protocol consists of all minuta deed, lists (registers) and the annual list of the notarial deed (Repertoria). Notary law Regulation specifies in Article 62 paragraph (1) of the things that must be done if a Notary died and in Article 62 paragraph (2) set if a Notary dismissed or moved. In cases were the heirs or notary himself must report the incident to the district court or the governor. Article 63 specifies that officials who received the notice should immediately appoint a replacement. This successor must immediately go to where the protocol is to receive all minuta, lists, Repertoria and Klapper. ${ }^{18}$ (Article 62 and 63 has been repealed by Act No. 33 of 1954 regarding Notary Public Deputy and Deputy Notary Provisional).

The sequence of the takeover of the protocol is as follows: the heirs of Notary who died or notaries who stopped to pass the protocol to the replacement, then substitute the newly appointed Notary. Then, according to Article 6 and 7 of Act No. 33 of 1954 and Article 64 PJN specified in terms of a Notary died or stopped, it must be reported to the court and the replacement switch protocols to the Notary newly appointed. The provisions of the law regarding the transfer protocol can be seen that the protocol does not belong to the notary who made it or mastered.

In connection with the transfer and protocol receiver notary, notary protocol receiver does not have enough space to accommodate bundles of minuta. PJN made each year according to 12 books. When a Notary worked somewhere for 15 years, the number of books to be delivered is 180 pieces, even in one month there are several notaries who made more than 100 certificates or more. One can imagine how thick the bundle minuta deed and difficulties protocol receiver to hold them. According PJN for one month of the book and can not be two or more

\footnotetext{
${ }^{16}$ Notary deed has been made on paper in general are sold freely on the market. Supposed to prevent counterfeiting or other legal action that can damage Notary and society, so that the deed of Notary made with special paper (security printing) which inside (each sheet) contains the state emblem (an eagle) and the symbol of the organization Notary (such as the Indonesian Notaries Association/INI )

${ }^{17}$ Habib Adjie, Op. Cit., p. 153

${ }^{18}$ What is meant by Klapper is the Client index.
} 
books. After UUJN effect, allowed two books or more. This can be seen in Article 16 paragraph (1) letter $f$ UUJN bind certificate stating that he made in the first month to book that contains no more than 50 certificates.

Normatively, Minuta Deed, copy of Deed and Deed Quotations shall be made in Indonesian. The use of Indonesian in Minuta Deed, copy of Deed and Deed Excerpt part Deed formal aspect, because Deed must be made according to the forms and procedures stipulated in the Notary law. ${ }^{19}$

Mrs. Nurlaelah argue that any such Minuta deed then stapled neatly organized in accordance with the order number and stored in a storage rack bundles of minutes of the deed along with supporting data. ${ }^{20}$ Notaries in his duties and shall be based normatively to the rules of law relating to the actions to be taken and then poured in deed. Acting pursuant to the applicable law would provide legal certainty to the parties, that the deed made before or by a notary public in accordance with applicable law, so that in case of problems notarial deed can be a guide to the parties. ${ }^{21}$

The loss of the Minuta deed besides complicate the Notary also complicate the public (client) who has made a deed ${ }^{22}$ of the notary who asked for a copy of the deed for deed the clients also destroyed due to natural disasters. ${ }^{23}$ For example, there is the client (the public) the notary who came to the notary office to be made wills holographic and secret, long-term contracts and other agreements made prior to the occurrence of natural disasters. This will make it difficult for all parties (notaries and clients) if the Minuta deed lost. With the storage of documents (minutes of) the notary is made in the form of electronic documents at any time if necessary can be opened when the Minuta deed damaged or lost due to a natural disaster. How minuta storage as it can be done by the Notary as a form of security if the notarial Minuta deed damaged or lost due to a natural disaster.

Replacement Procedures and Mechanisms of Lost Minuta Due Natural Disaster In Kota Palu, Central Celebescan be made the statement that the notary with Lost Minuta Deed to the police, but if the minutes of the deed is lost due to force majeure or break up the core of the minutes of the deed can not be read again the

\footnotetext{
${ }^{19}$ Adjie, Habib. (2015). Penafsiran Tematik Hukum Notaris Indonesia. Bandung: Refika Aditama. p. 189

20 Interview with Ms. Nurlaelah as the Office of the Human Rights Ministry, Central Celebes province on January 7, 2020 At 14:00 pm

${ }^{21}$ Adjie, Habib. (2009). Meneropong Khazanah Notaris dan PPAT Indonesia (Kumpulan Tulisan tentang Notaris dan PPAT). Bandung: Citra Aditya Bakti. p. 185

${ }^{22}$ Fuditia, Megacaesa., \& Mashdurohatun, Anis. (2020). Protection Against Recipients Notary Deed That Allegedly Protocol To The Legal Issue In Semarang. JURNAL AKTA: Vol.7, No. 2, 177-182. Retrieved from http://jurnal.unissula.ac.id/index.php/akta/article/view/7888

${ }^{23}$ Interviews with Indra Bayu Sujana, SH., M.Kn, in Palu, Central Celebes on January 7, 2020, 10:00 $\mathrm{pm}$
} 
notary is obliged to make an official report which is then later the official report was submitted to the MPW or MPD.

After the news of the event through to the MPW or MPD then the MPW or sanctions would sanction a written warning to dismissal with no respect in accordance with the severity of the violation of the notary. It self sanctions as a compulsion of law, as well as to provide awareness to those who violate them, that an act done was not in accordance with the applicable law, and to restore concerned to act in accordance with applicable laws, as well as to maintain the balance of passage a legal rule.

The sanctions are aimed against notaries also as awareness, that a notary public in the conduct of their office has violated the provisions concerning the implementation of the notary office duties as stated in UUJN and to restore the notary acts in performing the duties of office to order in accordance with UUJN. In addition, sanctions against notaries also to protect the public from the notary acts that could harm, such as a deed that does not protect the rights in question as the deed. Sanctions are to preserve the dignity of the notary institution as an institution of trust because when notary violations, can reduce public confidence in the notary. Individual sanctions against the notary is an agony and the stakes in the running of their office,

\subsection{Barriers and Solutions Procedures and Mechanisms Replacement of Lost Minuta Due Natural Disaster In Kota Palu, Central Celebes}

The tsunami disaster is the biggest natural disasters in Indonesia over the last decade in terms of casualties and the destruction of public facilities and infrastructure. The disaster has resulted in the loss of people, destruction of houses, buildings, and infrastructure, loss of objects, identity documents and other legal transaction documents. The tsunami disaster has resulted in the most crime such as looting, allegations of child trafficking, falsification of reports (markup) the number of refugees and non-functioning of public institutions normally.

Conditions mentioned above shows that the lives of the people who usually do normally not be able to run, including the system of government and the legal system. Government and legal system abnormalities affected by natural disasters in Central Celebes Palu particularly focused on three (3) obstacles, such as physical infrastructure, legal infrastructure and human resources. Human resources administration system run many dead or missing, the physical infrastructure to run the government system was destroyed, records or documents needed to run the government and legal system was destroyed.

Article 1 point to 13 in UUJN explain that Notary has the obligation to store and maintain documents related to the notary but the tsunami disaster is a natural state is not unexpected that cause broken or missing minutes of a notarial deed 
which is also part of the protocol notary public, this incident is not intentional and beyond the reach of reason than that of the notary notarized affected by natural disasters can not be held accountable to the Minuta deed damaged or lost because disasters arising from natural factors such as earthquakes, tsunamis and other natural disasters is not due to negligence of the notary.

Damaged or missing minutes of a notary deed took place outside the notary powers since the Tsunami is a Force Majeure (Circumstances forced) ${ }^{24}$ so the situation is beyond the power of man. ${ }^{25}$ Although notary can not be held accountable to the minutes of the deed is lost or damaged due to natural disasters, but the notary has a moral responsibility to report immediately on the occurrence of natural disasters which cause damage to the notary's office, including the loss of documents notary to the Ministry of Justice and Human Rights Republic of Indonesia (now the Ministry of Justice and Human Rights of the Republic of Indonesia).

Barriers Replacement Procedures and Mechanisms of Lost Minuta Due Natural Disaster in Kota Palu, Central Celebes is as follows:

a. Make a report to the police to report content that the notary concerned has lost all documents and other important files.

b. Send the report to the Minister of Justice and Human Rights of the Republic of Indonesia concerning the condition of the notary's office damaged by natural disasters.

c. send a letter containing a report to the Director of the Department of Civil Law and Human Rights of the Republic of Indonesia, Directorate General of Legal Administration with details:

1) Disaster reports about the condition of disaster damaged accompanied by evidence of the notary office in the form of image conditions.

2) Reports loss in connection with the assignment document file position as a Notary Public in the form of the original Decree of appointment as a notary, Minuta deed, Klapper, legalization, Waarmerking, Repertorium, a diploma from the primary level to the level of Notary and other important documents.

3) Based on these reports the notary in question asking and begging the instructions to be given the facilities and exemptions to be given a duplicate Decree of Appointment as Notary.

4) In the report Notary concerned also informed him that the new address in the line of duty as a Notary office.

5) Based on the application of the notary of the Government issued Decree because Appointment originals have been lost as a result of natural disasters occurring in the form of duplicate Decree of the appointment by the Minister of Law and Human Rights in lieu of the Decree.

\footnotetext{
${ }^{24}$ Force majeure is a condition of force caused by a natural event that can not be predicted and avoided by everyone because it is naturally without the element of intent.

${ }^{25}$ Interview with Ms. Nurlaelah, Op.Cit.
} 
6) Based duplicate decree issued by the Minister of Law and Human notary can perform tasks as a notary office as before. Thus the notary freed from all responsibility and obligation for the minutes of the notary lost due to natural disaster.

In connection with the above description, the solutions to overcome these barriers Replacement Procedures and Mechanisms of Lost Minuta Due Natural Disaster in Kota Palu, Central Celebes is as follows:

a. Heirs to apply for approval of the minutes of the notary deed or protocol to the notary who willing to accept the minutes of a notary deed or protocol of the notary who had died or disappeared because of natural disasters.

b. notary willing to accept the minutes of a notary deed or protocol to apply to the Minister of Justice and Human Rights of the Supervisory Council cq Central Celebes region Indonesia concerning the appointment of the protocol.

c. after a petition submitted and accepted by the Supervisory Council of the Territory, then the Regional Supervisory Council issued a decree on appointment of notaries container protocol of notary who died or disappeared because of natural disasters.

\section{Closing}

In that cases the notary's not delay and immediately report to the Ministry of Law and Human Rights regarding the minutes of the deed damaged by natural disasters which cause damage to the office of the notary so minutes of the deed destroyed so that the back of the notary public can be protected from the claims of the client notary who also became victims natural. And required additional settings on minuta storage deed made electronically as save minuta deed in the flash disk or scan after the scan can also be stored on a server that is monitored by the Ministry of Justice to be more organized.

\section{References}

Journal:

[1] Fuditia, Mega caesa., \& Mashdurohatun, Anis. (2020). Protection Against Recipients Notary Deed That Allegedly Protocol To The Legal Issue In Semarang. JURNAL AKTA: Vol.7, No. 2, 177-182. Retrieved from http://jurnal.unissula.ac.id/index.php/akta/article/view/7888

[2] Herlina, Lely. (2016). Jurnal: "Analisis Yuridis Terhadap Kelalaian Notaris Dalam Penyimpanan Minuta Akta". Malang: Universitas Brawijaya 
Books:

[1] Adjie, Habib. (2009). Meneropong Khazanah Notaris dan PPAT Indonesia (Kumpulan Tulisan tentang Notaris dan PPAT). Bandung: Citra Aditya Bakti

[2] Adjie, Habib. (2005). Undang-Undang Jabatan Notaris (UUJN) Sebagai Unifikasi Hukum Pengaturan Notaris, Renvoi, Nomor 28 of III, 3 September 2005

[3] Adjie, Habib. (2015). Penafsiran Tematik Hukum Notaris Indonesia. Bandung: Refika Aditama

[4] Ali, Achmad. (2009). Menguak Teori Hukum (Legal Theory) dan Teori Peradilan (Judical prudence) termasuk Interpretasi Undang-Undang (Legisprudence). Jakarta: Kencana

[5] Ali, Zainuddin. (2009). Metode Penelitian Hukum. Jakarta: Sinar Grafika

[6] C.S.T.Kansil. (1989). Pengantar IImu Hukum Dan Tata Hukum Indonesia. Jakarta: Balai Pustaka

[7] Djamali, R. Abdoel. (1993). Pengantar Hukum Indonesia. Jakarta: Raja Grafindo Persada.

[8] Notodisoerjo, R. Soegondo. (1993). Hukum Notaris Indonesia Suatu Penjelasan. Jakarta: Rajawali Pers

[9] Soemitro, Roni Hanitijo. (1988). Metode Penelitian Hukum dan Jurimetri. Jakarta: Ghalia Indonesia

[10] Surakhmad, Winarno. (1978). Dasar dan Teknik Research. Bandung: Tarsito

[11] Tosa, A. Halim. (1996). Pengantar Ilmu Hukum Indonesia. Banda Aceh: Faculty of Syariah IAIN Ar-Raniry

Regulations:

[1] Act No. 2 of 2014 concerning Amendments to Act No. 30 of 2004 concerning the Position of Notary Public

[2] Act No. 42 of 2009 concerning the third amendment to Act No. 8 of 1983 concerning Value Added Tax and Services and Sales Tax on Goods and Services and Sales Tax on Luxury Goods

[3] Government Regulation Number 37 of 1998 concerning PPAT Position Regulations 
Interviews:

[1] Interview with Ms. Nurlaelah as the Office of the Human Rights Ministry, Central Celebes province on January 7, 2020 At 14:00 pm

[2] Interviews with Indra Bayu Sujana, SH., M.Kn, in Palu, Central Celebes on January $7,2020,10: 00$ pm 